\title{
ir
}

\section{METÁFORA, PUESTA EN ESCENA Y PÚBLICO EN CALDERÓN}

\author{
Alejandro Higashi \\ Universidad Autónoma Metropolitana / Iztapalapa \\ [Anuario calderoniano (ISSN: 1888-8046), 1, 2008, pp. 223-244]
}

El título de este artículo bien pudo haber sido una pregunta: ¿qué se requiere para escenificar una metáfora? Si, advertidos de la complejidad de la «simple» metáfora (que puede ser lingüística, nominal apositiva, adjetiva, predicativa, comparativa, circunstancial; metáfora verbal y adverbial; metáfora recíproca, metáfora continuada y metáfora obsesiva; según la clasificación de Carmen Bobes Naves ${ }^{1}$ ), también consideramos que se trata de «un fenómeno que desborda los límites del lenguaje y es independiente de él, pues es posible en otros sistemas de signos y con objetos que se interpretan como signos si un lector o un observador los pone en relación de sentido, o en relaciones expresivas" ${ }^{2}$, habremos tomado consciencia del problema al que nos enfrentamos. En el teatro, la complejidad de la metáfora literaria (muy lejana sin duda de las metáforas sencillas estudiadas por los lingüistas, a menudo centradas en meras analogías léxicas) coincide con la complejidad de los códigos semióticos involucrados en la representación y con un tercer factor no menos complejo: la recepción del público, fi-

\footnotetext{
${ }^{1}$ Bobes Naves, 2004, pp. 166-212.

2 Bobes Naves, 2004, p. 24.
} 
gura responsable de crear una red de sentido eficaz, ya sea por resultar familiar (en cuyo caso puede hablarse de una recepción pasiva), ya sea por considerarse sorprendente (en cuyo caso su descodificación depende de las capacidades individuales del receptor, quien pasa a una posición más activa frente al sentido del texto literario). En el teatro, las metáforas más explotadas son sin duda aquellas directamente relacionadas con la modelización del imaginario espacial (las metáforas cronotópicas) $^{3}$, pero no hay que perder de vista la presencia de otras metáforas complejas que involucran, para su correcto desciframiento al hilo de la representación teatral, la estrecha colaboración entre los recursos del texto espectacular y los del texto dramático. En el caso de la representación teatral, la metáfora no sólo es una figura de estilo o de pensamiento; muchas veces, la metáfora encarna en un espacio y un tiempo dentro del escenario, especialmente en los casos en que la metáfora lingüística regresa a su origen plástico, enriquecido ahora ya no sólo por los conceptos, sino también por las más ricas posibilidades de la representación.

Las metáforas en el siglo XVII, por otro lado, no andaban solas. La imitatio como una forma de rivalidad creativa ayudó a formar mapas conceptuales que podían pasar con libertad del manuscrito poético a la representación escénica, apoyándose uno en el éxito del otro y viceversa. Aunque en muchos casos el teatro parece apropiarse de estas formas innovadoras como parte de una lengua literaria, sin apenas cambio, son más las ocasiones en las que puede palparse una preocupación real de los distintos autores por lograr, pese a todo, una eficacia comunicativa. Como nos ha hecho notar Déodat-Kessedjian, Calderón fue un maestro en el difícil arte de representar lo irrepresentable: el amor, la vergüenza, el dolor... todo ello puesto ante los ojos con la hiperbólica fuerza de lo incomunicable... y paradójicamente recreado, al mismo tiempo, con las herramientas de que dota el lenguaje y la representación: exclamación, oxímoron y antítesis, reticencia, retórica condicional, preterición, metáfora, didascalias, interrupciones, apartes, esticomitias, etc ${ }^{4}$. Esta misma irrepresentabilidad de la metáfora fue salvada también por medio de recursos textuales y escénicos que favorecieran la comunión del mensaje con el público.

${ }^{3}$ Bobes Naves, 2004, pp. 32-39.

${ }^{4}$ Déodat-Kessedjian, 1999, pp. 39-54. 
La lengua literaria de la época es un auxilio irremplazable para orientar al público del teatro en el desciframiento de los «nuevos» sentidos que inaugura el uso metafórico. Como señala Bobes Naves, «la relación metafórica sorprende al lector porque altera la convencionalidad del sistema e introduce una relación nueva entre dos términos»; pero no hay que perder de vista que «también la metáfora literaria puede repetirse con variantes mínimas y hacerse tópica de una etapa histórica o de un movimiento literario $»^{5}$. Esta verdad resulta evidente para la lengua literaria del siglo XVII; ya Carreira se ha encargado de recordarnos que «la forma de pensar, de leer y de escribir en tiempos de Góngora era distinta de la actual», ahí donde "la palabra, considerada o utilizada por un humanista, se insertaba en un eje más diacrónico que sincrónico» ${ }^{6}$. La lectura diacrónica implicaba una particular atención a las sutiles modificaciones del significado de las palabras y aquí la «novedad» de la metáfora tenía que atemperarse por la huella de su propia historia. No se trataba sólo de interpretar de acuerdo a la subjetividad del propio público, sino de acuerdo al complejo tramado histórico que se tejía metáfora tras metáfora. En palabras de Aurora Egido, «la existencia de un canon obligaba a tenerlo en cuenta, incluso hasta para separarse de él o buscar un canon nuevo, como de hecho se hizo en todos los terrenos» ${ }^{7}$.

En el caso de Calderón, su brillante metáfora se apoya muchas veces en una tradición literaria de cuño gongorino y en un público cortesano que reconoce esa tradición. Ya señala Javier Aparicio Maydeu que

cuando el dramaturgo cuenta con apenas veinte años, los poemas de Góngora circulan en forma de manuscrito por Madrid, transmitiéndose, recitándose y escuchándose hasta la saciedad. El verso sonoro y grandilocuente del poeta cordobés, con sus cultismos greco-latinos y alambicada sintaxis [...], alcanzó a ser una de las influencias básicas en el joven Calderón, quien se apropió de innumerables versos gongorinos e iluminó con ellos muchas piezas de su teatro, que ya venían marcadas por una fuerte trabazón lógica del discurso, por una hipertrofia de la argumentación y el razonamiento, por el silogismo de trabazón escolástica [...] y

\footnotetext{
5 Bobes Naves, 2004, pp. 31 y 33.

${ }^{6}$ Carreira, 1998, p. 48.

7 Egido, 2004, p. 199.
} 
por la sintaxis de simetrías, paralelismos y correlaciones que aprendió de la Ratio Studiorum en las aulas del Colegio Imperial de la Compañía de Jesús ${ }^{8}$.

La metáfora calderoniana será, en consecuencia, trasunto de esta dualidad: «sus imágenes son — apunta Rodríguez Cuadros- como golpes de luz que, de repente, iluminan un escenario lleno de atormentadas preguntas o razonamientos» ${ }^{9}$. Esta rica metáfora que supone «una ruptura o extrañamiento del orden racional, una radical extracción de un objeto de su percepción automatizada» ${ }^{10}$, sólo cobra sentido cuando un público educado y curioso participa activamente en el proceso creativo como el polo «desautomatizador». Es por ello por lo que, como ya nos previene Arellano, el cultismo de Calderón «se halla de manera especial en las comedias palaciegas, las suntuosas fiestas mitológicas o caballerescas, cuyo público era el de la corte. Tanto los temas como el público exigían un registro exquisito y peregrino, lo que en el Siglo de Oro equivale a decir gongorismo» ${ }^{11}$. Resulta evidente que ciertas texturas estilísticas predominan en función de un público particular que está dispuesto a disfrutar la puesta en escena, pero también a vérselas con un lenguaje rico en metáforas cuya comprensión exige tanta atención y tanta participación como lo exigía la propia poesía gongorina. $\mathrm{O}$ casi, porque en el teatro se materializaba la paradoja que ya en la lectura resultaba verdad común, según la cual, en formulación de Egido, «el lector no puede avanzar si no se para, y de esa paradoja surge el nuevo deleite que propiciaron tanto los equívocos de un Quevedo o de un Mateo Alemán como las oscuridades gongorinas» ${ }^{12}$. El deleite cifrado en esta fórmula de Egido («el lector no puede avanzar si no se para») funcionaría muy mal para el teatro, donde el público no podía detenerse a reflexionar, a riesgo de suspender el espectáculo teatral. Funcionaría muy mal, si no fuese porque el mismo teatro proveía de las herramientas para limar las dificultades de la metáfora culterana y ofrecerla de modo que la com-

\footnotetext{
${ }^{8}$ Aparicio Maydeu, 2003, p. 1103.

${ }^{9}$ Rodríguez Cuadros, 2002, p. 164.

${ }^{10}$ Rodríguez Cuadros, 2002, p. 164.

11 Arellano, 2001, p. 50.

12 Egido, 2004, p. 199.
} 
prensión del público quedase garantizada por los propios recursos teatrales, tanto del texto dramático como del texto espectacular.

Hablemos, para ilustrar la teoría, de una metáfora exitosa que vio la luz en la Fábula de Polifemo y Galatea gongorina, luego aprovechada por otros ingenios del siglo y, especialmente, por Calderón (quien, como nos previene Arellano, la repitió a menudo en otras comedias: Amar después de la muerte, Duelos de amor y lealtad, La Virgen del Sagrario, Las cadenas del demonio, Los dos amantes del cielo, La puente de Mantible, Los hijos de la fortuna, La púrpura de la rosa ${ }^{13}$ ). Me refiero al «formidable de la tierra / bostezo, el melancólico vacío / a Polifemo, horror de aquella sierra, / bárbara choza es, albergue umbrío» ${ }^{14}$.

La metáfora por la cual la imagen de una cueva se recrea en el imaginario cultural como un "formidable de la tierra / bostezo" y un «melancólico vacío» no fue, por supuesto, una idea original de Góngora, como mucho de lo que toca a la descripción del Cíclope en deuda clara con el modelo virgiliano ${ }^{15}$. En Virgilio se juega ya con la ambigüedad del latín «hiatus», al mismo tiempo «bostezo» o «acción de abrir la boca» y "grieta» o "hendidura», en el verso «Spelunca alta fuit, vastoque inmanis hiatu, / scrupea, tuto lacu nigro nemorumque tenebris» (En.VI, 237-238) que Gregorio Hernández de Velasco recrea, con arrebatado abuso adjetival, en su traducción de 1557 como «hubo una honda y espaciosa cueva, / de una ancha, horrible y tenebrosa boca, / áspera y escabrosa, con gran suma / de pedrezuelas toscas, cuya entrada / estaba defendida a todas partes / de un negro lago y de un escuro bosque» y que Diego López, en su traducción en prosa de 1601, simplonamente nos transmite como "hubo una honda cueva, y muy grande con larga boca, áspera, segura con el lago negro y con las sombras de la selva» ${ }^{16}$. Góngora no sólo humaniza el paisaje (la cueva es un bostezo, las ramas de los árboles son greñas ${ }^{17}$ ) en adelanto de la grotesca magnificencia del gigante, que será poco después «un monte $[. .$.$] de miembros eminente» (v. 49), sino que logra condensar$ en una metáfora económica el sentido referencial de la metáfora y el

13 Arellano, 2001, p. 49.

14 Góngora, Fábula de Polifemo y Galatea, vv. 41-44.

15 Como ya nos recuerda Vilanova, 1957, p. 409.

16 Ambas referencias en Vilanova, 1957, p. 409.

17 Vilanova, 1957, p. 410. 
sentimiento de terror que despierta el locus terribilis en la mente de sus lectores. Eso, al menos, puede deducirse del éxito de este entramado metafórico en autores posteriores, desde el pálido hurto como sucede con Francisco Santos en «una cueva bruta, paca o bostezo de la tierra» ${ }^{18}$ o con el mismo Calderón en Los dos amantes del cielo («porque esa abierta boca, / bostezo formidable de la roca, / el paso me detuvo» ${ }^{19}$ ) o cuando en No hay más fortuna que Dios, la Hermosura cae por el escotillón y la Milicia expresa «La Hermosura, / ciega en sus divertimientos, / en una sima ha caído, / cuyo horroroso bostezo / de la tierra, da pavor ${ }^{20}$ ) hasta la síntesis un poco más creativa en la que el «formidable de la tierra / bostezo» queda indefectiblemente ligado al «melancólico vacío», para expresar al mismo tiempo el espacio y la naturaleza sombría del mismo lugar que recrea (pues, como explica Pellicer en sus Lecciones solemnes, «llámale melancólico, por ser la escuridad causa de la melancolía» ${ }^{21}$ ); así, los bostezos se vuelven ahora melancólicos en «un / melancólico bostezo / del peñasco» (Amar después de la muerte ${ }^{22}$ ), "Melancólico bostezo / ya del centro de la tierra / es la pavorosa gruta» (La fiera, el rayo y la piedra ${ }^{23}$ ) o en "abierta una boca, un / melancólico bostezo / del peñasco» (El Tuzaní del Alpujarra ${ }^{24}$ ). Otras veces, los bostezos sencillamente se vuelven oscuros, recurriendo simplonamente al adjetivo en una actitud ya bastante desprovista del suntuoso ropaje culterano, o a fáciles construcciones metafóricas que aluden a esta naturaleza sombría. Así, mientras para Calderón el bostezo es «lóbrego» ("Abra la infausta boca / el lóbrego bostezo de esta roca», El segundo blasón del Austria ${ }^{25}$ ), para Diamante será simplemente "oscuro» («una mal formada cueva, / en cuyo obscuro bostezo / el Santo Isidoro habita», El negro más prodigioso ${ }^{26}$ ) como para otros autores: Rojas Zorrilla escribe que Reinaldos anda «del más obscuro bostezo, / que aborta la madre tierra / al más encumbrado

18 Francisco Santos, Las tarascas de Madrid, p. 255.

19 Calderón de la Barca, Los dos amantes del cielo, II, vv. 551-552.

20 Calderón de la Barca, No hay más fortuna que Dios, vv. 1562-1566.

${ }^{21}$ Vilanova, 1957, p. 408.

22 Calderón de la Barca, Amar después de la muerte, II, vv. 861-863.

23 Calderón de la Barca, La fiera, el rayo y la piedra, I, vv. 313-315.

24 Calderón de la Barca, El Tuzaní del Alpujarra, II, vv. 916-918.

25 Calderón de la Barca, El segundo blasón del Austria, vv. 11-12.

${ }^{26}$ Juan Bautista Diamante, El negro más prodigioso, II, vv. 171-173. 
cerro" (Los celos de Rodamonte ${ }^{27}$ ) y Antonio Zamora hace decir a su Ciboria "y pues en esa gruta, / pardo bostezo a la pereza bruta, / muriendo vivo" (Judas Iscariote ${ }^{28}$ ).

Un análisis comparativo de los cuerpos de significación levantados en torno a esta metáfora resulta bastante ilustrativo de las transformaciones que operan para la intelección de la misma en un género exclusivamente textual, como sucede con la poesía, y en otro con varios planos de significación, como el teatro. En Polifemo y Galatea, la comprensión de este "formidable de la tierra / bostezo" se garantiza por la mención explícita y unión, diez versos antes, de las dos series o isotopías que confluyen: cuando Góngora anuncia en el pareado de la cuarta estrofa que "Allí una alta roca / mordaza es a una gruta, de su boca» (vv. 31-32), inaugura el proceso de humanización del locus terribilis que concluirá con la descripción de Polifemo (estrofas 7-12). $\mathrm{Al}$ respecto, señala Pellicer que la mordaza es un «instrumento penoso, con que se castiga a los blasfemos, échanla a la lengua para para impedir la voz» y que para «amordazar» con una piedra la entrada de la gruta «ayuda a la alusión llamarse la puerta de la cueva boca en la erudición: Virg. lib. 2 AEn. specus lato ore» ${ }^{29}$, lo que apunta ya a una comprensión metafórica y diacrónica de esta boca: mientras para el mundo clásico la acepción normal sería "entrada de la cueva», Góngora anima el término con la mera presencia de esta mordaza. Como ha señalado Pabst con acierto, mordaza se transforma en un término clave que humaniza y renueva el sentido de la metáfora lexicalizada ${ }^{30}$, siguiendo una técnica ya bien explicada por Buxó: «el hecho de partir directamente de un término metafórico lexicalizado, trae como consecuencia que, frecuentemente, se entrecrucen los planos reales e imaginarios, obligando así al lector a orientarse por medio de todo el contexto» ${ }^{31}$. Siguiendo sus enseñanzas en la metáfora gongorina, la serie real correspondería a:
(a) alta roca
(b) gruta

27 Francisco Rojas Zorrilla, Los celos de Rodamonte, III, vv. 488-490.

28 Antonio Zamora, Judas Iscariote, II, vv. 337-339.

${ }^{29}$ Vilanova, 1957 , pp. 364-365.

${ }^{30}$ Vilanova, 1957, p. 367.

31 Buxó, 1960, p. 93. 
y la serie metafórica estaría expresada por:
(a') mordaza
(b') boca

Ambas series o isotopías tendrán resonancia en «formidable de la tierra / bostezo» por la relación contextual que guardan ambos pasajes con la boca inanimada (en su acepción de «entrada de la cueva») y con la boca animada (primero "amordazada» y ahora «bostezante»).

Calderón, en una apretada sucesión de metáforas, condensa este contexto para describir la gruta en la que se ocultan las Parcas en la jornada primera de La fiera, el rayo y la piedra, estrenada la noche de mayo de 1652 en el Coliseo del Buen Retiro de Madrid. Aquí, delante de la gruta y a la espera del oráculo que desencadena el enigma de la obra, Céfiro, príncipe de la Trinacria (según se indica en I, vv. 273-274), instará a Ifis y a Pigmaleón a descorrer la peña que oculta el umbral de las Parcas:

$\begin{array}{ll}\text { CÉFIro } & \begin{array}{l}\text { Pues desquiciemos la puerta } \\ \text { de este risco, que mordaza } \\ \text { es de su boca funesta. }\end{array} \\ \text { IFIS } & \begin{array}{l}\text { Melancólico bostezo } \\ \text { ya del centro de la tierra } \\ \text { es la pavorosa gruta. }\end{array} \\ & \text { (I, vv. 310-315) }\end{array}$

Calderón confía menos en su público, aunque ciertamente el recurso de la gruta en escena no es desconocido para el adepto al teatro cortesano y de corral y Calderón no ha dudado en aprovecharlo incluso en comedias de capa y espada (como han señalado Arellano ${ }^{32}$ o Varey ${ }^{33}$ ). En vez de un sutil sistema de correspondencias entre el mundo de la ficción y el de la realidad cifrado en la intelección del concepto central mordaza, confia en un mecanismo de correlaciones sintácticas del tipo a es a', escalonadas en forma de espejo, donde a es $a^{\prime}$ y $b^{\prime} e s$, de modo que los contenidos referenciales abren y cierran la descripción de la cueva como una especie de marco:

32 Arellano, 2003 y 2004.

${ }^{33}$ Varey, 2003. 
(a) Puerta de este risco

es

(a') mordaza de su boca funesta.

(b’) Melancólico bostezo

es

(b) la pavorosa gruta.

El texto cuenta con apoyos visuales dentro de la puesta en escena, lo que explica la relevancia que da Calderón a los contenidos referenciales, presentes al principio y al final de esta polifémica, si cabe, descripción. La última mudanza de la escena, cuando Céfiro, Pigmaleón e Ifis ingresan al teatro momentos antes, previene justamente en el foro, al fondo del todo y en el centro de visión del público asistente, la presencia de bastidores que figuran peñascos («Múdase el teatro en perspectiva de bosque muy lóbrego, y por foro, o últimos bastidores, unos peñascos donde se abrió después la gruta de las Parcas", Acot., v. 224). Al descorrerse los bastidores, luego de los diálogos de Céfiro e Ifis, aparece al fondo del todo el umbral de las Parcas, según la acotación que indica «Abriose la gruta y viéronse dentro, con sola la poca luz que bastase distinguirlas, las tres Parcas vestidas con unas túnicas tristes, el cabello suelto y mal peinado [...]» (Acot., v. 318). Los versos en boca de Céfiro e Ifis retratan justamente la transición entre estos dos momentos y de ahí que la serie metafórica quede enmarcada por la serie referencial: la descripción que inicia con la puerta, a la vista del público que asiste al Coliseo del Buen Retiro, termina con la presentación en escena del interior de la gruta, salón donde las Parcas cumplen su infame tarea. Así, la escenografía crea una estrecha relación de solidaridad con el texto dramático: lo que principia como «puerta» cerrada en el texto y la escenografia, termina como "pavorosa gruta» una vez descubierta la peña-bastidor que la obstruía.

La diferencia más obvia en los mecanismos a los que recurren estos autores en ambas compositiones loci es la confianza depositada en el público. En el caso de Góngora, la interpretación de la metáfora descansa en una lectura cuidadosa de dos secciones del poema interrelacionadas, lo que supone un lector reflexivo que puede volver sobre sus pasos, ese que "no puede avanzar si no se para»; en el caso de 
Calderón, las metáforas terminan de construir lo que el público puede ver en escena, especificando su naturaleza de locus terribilis. Si, como ha señalado Buxó, los elementos de la realidad en Góngora «no se ordenan tanto en la experiencia como dentro de los mecanismos inmutables de un sistema retórico y mitológico» ${ }^{34}$, la misma metáfora en Calderón recurre a mecanismos muy locales de interpretación: no se confia el autor dramático en otras resonancias dentro del ir y venir de su obra, sino que las decodifica inmediatamente in situ recurriendo al paralelismo y, al mismo tiempo, apoyándose en el aparato escenotécnico.

Si revisamos la misma metáfora cuando falta este soporte escenográfico, podremos comprobar los predicamentos que Calderón debe librar, pues ahora únicamente por medio de recursos textuales el actor puede descodificar delante del público los complejos contenidos referenciales que expresa. Así, por ejemplo, en Amar después de la muer te, el soldado Garcés narra el engaño al que lo somete un moro quien, «entre dos cerros [...] por los peñascos subiendo» (II, vv. 846-848), lo entrega a sus tropas. Huyendo, Garcés descubre una gruta a los pies de la muralla de la ciudad granadina de Galera y ahí se esconde (lo que, por otro lado, da ocasión para planear la estrategia con que se tomará: en vez de un cerco, sugiere Garcés «con fuego volarla» aprovechando estas minas en el subsuelo). Al tratarse de una narración diegética, sin apoyo escénico de ningún tipo, Calderón insiste quizá excesivamente en la serie real para que no quede duda de la explicación correspondiente en la serie metafórica. Así, dirá Garcés:

\author{
Inútil fue la defensa, \\ [...] cuando veo \\ debajo de las murallas \\ de Galera, donde llego, \\ abierta una boca, un \\ melancólico bostezo \\ del peñasco, sobre quien \\ estriba, que con el peso \\ del edificio, sin duda \\ gimió, y por quedar gimiendo \\ siempre no volvió a cerrarla,
}

34 Buxó, 1960, p. 91. 
y se le dejó entreabierto

(II, vv. 857-868)

Con cierto humor, Calderón carga las tintas en la humanización sutil de Góngora hasta la grotesca imagen de una tierra que gime con el peso de la construcción y no vuelve a cerrar la boca; frente a la apenas perceptible mordaza que anima la escena gongorina, aquí Calderón no teme abusar de verbos animados ("gimió», "quedar gimiendo», «no volvió a cerrarla», «le dejó entreabierto») hasta caricaturizar por completo a este sujeto inmaterial de lo que deja de ser metáfora para convertirse en una curiosa sinécdoque dentro de una hiperbólica cadena metafórica.

Otras metáforas con menor suerte dramática fueron el «Can del cielo» y la "salamandria del sol», en la plástica presentación que hace Góngora del joven Acis:
Salamandria del sol, vestido estrellas, latiendo el Can del cielo estaba, cuando (polvo el cabello, húmidas centellas, si no ardientes aljófares, sudando) llegó Acis.
(vv. 185-189)

Vale la pena recapturar el movimiento que imprime Góngora a esta imagen: ladrando el "Can del cielo», vestido de las propias estrellas que lo forman, entra en el sol y como una salamandra habita en este fuego; esta cadena metafórica describe simplemente la alineación de Sirio, en la constelación del Can Maior, con el Sol. Allí, el «Can del cielo» funciona como metáfora de la canícula, pero también como animada presentación de la constelación del Can, vestido de estrellas y viviendo como una salamandra en el fuego del sol sin quemarse, términos de la comparación donde con más claridad se manifiesta la construcción metafórica, como ya percibía Cuesta en su comentario: «de la manera que la salamandra no se ofende con el fuego, el Can celeste no siente el ardor del Sol: por esto don Luis tomó ocasión para usar de la metáfora y llamó salamandra del sol al Can» ${ }^{35}$. Aunque las autoridades latinas para respaldar el significado tradicional de los términos por separado sobran (el Can Maior responsable de la canícula y

${ }^{35}$ Ver Alonso, en su edición de Góngora, Fábula y Polifemo y Galatea, p. 509. 
la propiedad de la salamandra para andar en el fuego sin quemarse ${ }^{36}$ ), estas metáforas rara vez se aprovechan en el teatro. Respecto a la salamandra, por ejemplo, menudean los casos en que los amantes abrasados demandan el fuego del amor (del estilo "salamandra de mi amor, / vengo a vivir en tu ardor, / por no morir en tu hielo», Moreto ${ }^{37}$ ), aquellos donde la salamandra se identifica con un renacer de las cenizas, por asimilación con el ave Fénix ("Cielos, todo es dichas hoy, / quién fénix, y salamandra / en el fuego de tu sol, / cuando quemándose vive, / muere a renacer mejor?», Moreto ${ }^{38}$ ) o simplemente representa la hipérbole de un castigo («lasciva cruel Casandra, / digna siempre de arder en mayor fuego / que se suele quemar la salamandra, / que entre sus llamas vive con sosiego", Lope ${ }^{39}$ ). En general, la conexión entre el Can del cielo y la salamandra no resultó productiva para el teatro de la época ni para la poesía, probablemente por los conocimientos especializados que suponía su desciframiento.

Cuando Calderón echa mano de estos recursos, lo hace con precaución para salvar la poca familiaridad que muestra su público con ellos: si se trata de presentar la riqueza de los bienes con que naturaleza dota a los hombres, aprovecha como otros autores la gradatio que supone el par salamandra-fénix (así, la parra es una «siempre iluminada hoguera» donde "salamandra el sol se abrasa» y «fénix el sol se renueva», El árbol del mejor fruto ${ }^{40}$; en La sibila del Oriente, se presenta la magnificencia de la naturaleza en términos muy semejantes: aquí todo leño "es una aroma», toda copa "es una hoguera», toda peña "es un brasero", "holocausto destas selvas»; el monte completo es una "verde eminencia» y «una ara no más» de la naturaleza, «en cuya llama sabea / salamandra el sol se abrasa, / fenix el sol se renueva» ${ }^{41}$ ). En el caso de Celos aun del aire matan, la salamandra no es sólo una metáfora: Aura aparece en escena montada en una salamandra donde todo arde en

${ }^{36}$ Ver Alonso, en su edición de Góngora, Fábula y Polifemo y Galatea, pp. 508509.

37 Moreto, La fuerza de la ley, II, vv. 717-719.

38 Moreto, Hasta el fin nadie es dichoso, II, vv. 523-527.

39 Lope de Vega, El perseguido, III, vv. 1095-1098.

40 Calderón de la Barca, El árbol del mejor fruto, vv. 649-651.

41 Calderón de la Barca, La sibila del Oriente, I, vv. 813-834. 
fuego de amor e $\mathrm{ira}^{42}$. En fin, la imagen gongorina, en todo caso, parece adecuarse a la fórmula que ya ha deducido Javier Aparicio Maydeu

romances y asimismo fragmentos del Polifemo y otros poemas mayores de Góngora, que se acomodan como un guante a un teatro construido (notablemente en dramas y comedias palaciegas) sobre la base de largos y elaborados soliloquios, que a su vez producían un efecto a un tiempo de desbordamiento espacial de la escena - prolongando el espacio escénico hasta englobar el espacio del espectador-y de empatía con un público de hidrópica mirada al que se le forzaba a no distinguir límite alguno entre ambos espacios ${ }^{43}$.

El «Can del cielo», por supuesto, resulta todavía más raro, pues su imagen escapa por completo al imaginario popular y tampoco cuenta con el respaldo de una realidad paralela que ayude a desentrañar mejor el sentido de la metáfora. En este caso, la metáfora sólo cubre el espectro semántico gongorino, sin variantes y, por supuesto, con más o menos apoyos para una rápida interpretación según la disposición de la metáfora. En los casos en los que se especifica la naturaleza calurosa del ambiente, a menudo la metáfora está precedida por indicios explícitos que dejan saber al público el contenido referencial, sin apoyo escenográfico, con lo que la metáfora se transforma en una forma elegante de repetir contenidos ya bien entendidos. Así, la serie real precede a la serie metafórica y garantiza una comprensión precisa de la naturaleza del ambiente. En Eco y Narciso, por ejemplo, fatigados Bato y Narciso después de perseguir un corzo herido, propone Narciso descansar en un lecho sombreado, antesala de su encuentro fatídico con la fuente:

Entre aquellas ramas bellas
un poco estemos, pues ellas
impiden el arrebol
del sol, en tanto que al sol
late el can del cielo estrellas.

(III, vv. 2456-2460)

42 Calderón de la Barca, Celos aun del aire matan, II, v. 696 acot.

43 Aparicio Maydeu, 2003, p. 1104. 
La metáfora se coloca al final del breve parlamento, una vez que ha quedado bien claro para el público la configuración del espacio referido (el follaje que impide «el arrebol del sol»), la metáfora sólo es una amplificatio de la construcción espacial en el texto dramático: el Can del cielo lanza estrellas al sol que lo calientan más. Si el público no alcanzara a descifrar el contenido metafórico nada se pierde: el espacio referido es claro y sólo no lo sería el hecho secundario de ser un sol canicular.

Estas calas apuntan, sin duda, a una perspectiva más rica del fenómeno, en la que las metáforas de los grandes maestros forman un pautado que orienta de modos muy distintos la tradición literaria. Detrás de la desaliñada pobreza de aquellas metáforas que se repiten hasta la saciedad (es decir, hasta su lexicalización y consecuente anquilosamiento) como parte de una lengua literaria, puede palparse una preocupación real de los distintos autores por lograr, pese a todo, una eficacia comunicativa. Calderón se apropió de algunas metáforas gongorinas y con ello pudo recrear verbalmente un espacio fantástico en escena, retando al espectador del XVII a reconstruir este espacio dramático a partir de una retórica culterana de reconocida dificultad. Por más que los imitadores sólo parezcan eso, vulgares imitadores, las metáforas compartidas pueden ofrecer más claros vestigios de la manera en la que un autor del XVII enfrenta y triunfa sobre una tradición literaria, en la misma medida en que la continúa y consolida el espectáculo teatral. 


\section{Bibliografía}

Aparicio Maydeu, J., "Calderón de la Barca», en Historia del Teatro Español, I, De la Edad Media a los Siglos de Oro, dir. J. Huerta Calvo, Madrid, Gredos, 2003, s. $v$.

Arellano, I., Calderón y su escuela dramática, Madrid, Ediciones del Laberinto, 2001.

- «Espacios de la maravilla en los dramas de Calderón», en Loca ficta; los espacios de la maravilla en la Edad Media y Siglo de Oro, ed. I. Arellano, Madrid / Frankfurt am Main, Iberoamericana / Vervuert, 2003, pp. 41-56.

- «Algunos modelos de lo fantástico y maravilloso en Calderón», en Fantasía en la Edad Media y los Siglos de Oro, ed. N. Salvador Miguel, S. LópezRíos y E. Borrego Gutiérrez, Madrid / Frankfurt am Main, Iberoamericana / Vervuert, 2004, pp. 55-79.

Bobes Naves, C., La metáfora, Madrid, Gredos, 2004.

Buxó, J. P., Góngora en la poesía novohispana, México, Universidad Nacional Autónoma de México, 1960.

Calderón de la Barca, P., Amar después de la muerte, en Novena parte de Comedias de [...] publica Don Juan de Vera Tassis y Villarroel (Madrid, Por Francisco Sanz, 1691), en Teatro Español del Siglo de Oro 3.0, dir. M. C. Simón Palmer, CD-Rom, Chadwick-Healy, España, 1997-1998.

- Celos aun del aire matan, en Séptima parte de comedias de... Don Juan de Vera Tassis y Villarroel [Madrid, Por Francisco Sanz... 1683], en Teatro Español del Siglo de Oro 3.0, dir. M. C. Simón Palmer, CD-Rom, Chadwick-Healy, España, 1997-1998.

- El árbol del mejor fruto, en Autos sacramentales, alegoricos, $y$ historiales de... que saca a luz don Pedro de Pando y Mier... Parte segunda, en Teatro Español del Siglo de Oro 3.0, dir. M. C. Simón Palmer, CD-Rom, Chadwick-Healy, España, 1997-1998.

- El segundo blasón del Austria, en Autos sacramentales, alegóricos, y historiales de... que saca a luz don Pedro de Pando y Mier... Parte cuarta, en Teatro Español del Siglo de Oro 3.0, dir. M. C. Simón Palmer, CD-Rom, ChadwickHealy, España, 1997-1998.

- El Tuzaní del Alpujarra, en Quinta parte de comedias de..., en Teatro Español del Siglo de Oro 3.0, dir. M. C. Simón Palmer, CD-Rom, Chadwick-Healy, España, 1997-1998.

- Fuego de Dios en el querer bien, en Séptima parte de comedias de... publica Don Juan de Vera Tassis y Villarroel, en Teatro Español del Siglo de Oro 3.0, dir. M. C. Simón Palmer, CD-Rom, Chadwick-Healy, España, 1997-1998.

- La fiera, el rayo y la piedra, introd. M. Sánchez Mariana y ed. J. Portús, en Teatro mitológico, Autos sacramentales, Madrid, Castalia, 2001. 
- La sibila del Oriente, en Verdadera quinta parte de comedias de... publica Don Juan de Vera Tassis y Villarroel, en Teatro Español del Siglo de Oro 3.0, dir. M. C. Simón Palmer, CD-Rom, Chadwick-Healy, España, 1997-1998.

- Los dos amantes del cielo, en Verdadera quinta parte de comedias de... publica Don Juan de Vera Tassis y Villarroel, en Teatro Español del Siglo de Oro 3.0, dir. M. C. Simón Palmer, CD-Rom, Chadwick-Healy, España, 1997-1998.

- No hay más fortuna que Dios, en Autos sacramentales, alegoricos, y historiales de... que saca a luz don Pedro de Pando y Mier [...] Parte cuarta, en Teatro Español del Siglo de Oro 3.0, dir. M. C. Simón Palmer, CD-Rom, Chadwick-Healy, España, 1997-1998.

Carreira, A., Gongoremas, Barcelona, Península, 1998.

Déodat-Kessedjian, M. F., El silencio en el teatro de Calderón de la Barca, Madrid / Frankfurt am Main, Iberoamericana / Vervuert, 1999.

Diamante, J. B., El negro más prodigioso, en Comedias de... Segunda parte, en Teatro Español del Siglo de Oro 3.0, dir. M. C. Simón Palmer, CD-Rom, Chadwick-Healy, España, 1997-1998.

EgIdo, A., De la mano de Artemia, literatura, emblemática, mnemotecnia y arte en el Siglo de Oro, Barcelona, José J. Olañeta / Universitat de les Illes Balears, 2004.

Góngora, L. de, Fábula de Polifemo y Galatea, ed.A.A. Parker, Madrid, Cátedra, 1984.

- Fábula de Polifemo y Galatea, en D. Alonso, Góngora y el "Polifemo», Madrid, Gredos, 1994.

Moreto, A., Hasta el fin nadie es dichoso, en Primera parte de comedias de..., en Teatro Español del Siglo de Oro 3.0, dir. M. C. Simón Palmer, CD-Rom, Chadwick-Healy, España, 1997-1998.

- La fuerza de la ley, en Primera parte de comedias de..., en Teatro Español del Siglo de Oro 3.0, dir. M. C. Simón Palmer, CD-Rom, Chadwick-Healy, España, 1997-1998.

Rodríguez Cuadros, E., Calderón, Madrid, Síntesis, 2002.

Rojas Zorrilla, F, Los celos de Rodamonte, en Primera parte de las comedias de..., en Teatro Español del Siglo de Oro 3.0, dir. M. C. Simón Palmer, CDRom, Chadwick-Healy, España, 1997-1998.

Santos, F., Las tarascas de Madrid, ed. M. Navarro Pérez, Madrid, Instituto de Estudios Madrileños, 1976.

VAREY, J. E., «Calderón y sus trogloditas», en Cosmovisión y escenografía: el teatro español en el Siglo de Oro, Madrid, Castalia, 2003, pp. 249-261.

VeGA, L. de, El perseguido, en Las comedias del famoso poeta Lope de Vega..., en Teatro Español del Siglo de Oro 3.0, dir. M. C. Simón Palmer, CD-Rom, Chadwick-Healy, España, 1997-1998.

Vilanova, A., Las fuentes y los temas del Polifemo de Góngora, Madrid, CSIC, 1957. 
Zamora, A., Judas Iscariote, en Comedias de..., en Teatro Español del Siglo de Oro 3.0, dir. M. C. Simón Palmer, CD-Rom, Chadwick-Healy, España, 1997-1998. 
Anuario calderoniano, 1, 2008, pp. 223-244. 


\section{ANEXOS}

\section{EJEMPLO 1}

Allí, una alta roca mordaza es a una gruta, de su boca.

[...]

De este, pues, formidable de la tierra bostezo, el melancólico vacío

a Polifemo, horror de aquella sierra, bárbara choza es, albergue umbrío

(Fábula de Polifemo y Galatea, vv. 31-32 y 41-44, ed. cit. en bibliografia)

Serie real (inanimada) (a) alta roca

(b) gruta

Serie metafórica (animada) (a') mordaza

(b’) boca

\section{EJEMPLO 2}

Céfiro Pues desquiciemos la puerta de este risco, que mordaza es de su boca funesta.

IfIS Melancólico bostezo ya del centro de la tierra es la pavorosa gruta.

(La fiera, el rayo y la piedra, I, vv. 310-315, ed. cit. en bibliografia).

Serie real (a) Puerta de este risco

es

Serie metafórica (a') mordaza de su boca funesta

Serie metafórica (b’) Melancólico bostezo 
es

Serie real (b) la pavorosa gruta

EJEMPLO 3

GARCÉs Inútil fue la defensa, [... ] cuando veo debajo de las murallas de Galera, donde llego, abierta una boca, un melancólico bostezo del peñasco, sobre quien estriba, que con el peso del edificio, sin duda gimió, y por quedar gimiendo siempre no volvió a cerrarla, y se le dejó entreabierto

(Amar después de la muerte, ed. cit. en bibliografía).

Serie metafórica (animada)
(a) abierta una boca
(b) un melancólico bostezo
(c) sobre quien estriba el peso
(d) gimió
(e) y por quedar gimiendo
(f) siempre no volvió a cerrarla
(g) se le dejó entreabierto

Serie real (inanimada)

(b’) del peñasco

(c') con el peso del edificio 


\section{EJEMPLO 4}

Salamandria del sol, vestido estrellas, latiendo el Can del cielo estaba, cuando (polvo el cabello, húmidas centellas, si no ardientes aljófares, sudando) llegó Acis [...] (Polifemo, vv. 185-189).

Serie metafórica:
(a) ladrando el «Can del cielo»
(b) vestido de las propias estrellas que lo forman
(c) el Can del Cielo entra en el sol
(d) como una salamandra habita en este fuego

Serie real:

(a') brillando Sirio, en la constelación del Can Maior

(b') el Can Maior como una constelación

(c') unión de Sirio con el Sol

\section{EJEMPLO 5}

Entre aquellas ramas bellas un poco estemos, pues ellas impiden el arrebol del sol, en tanto que al sol late el can del cielo estrellas (Eco y Narciso, III, 2456-2460).

Serie real:

(a) invitación para estar a la sombra

(b) la sombra protege del arrebol del sol

Serie metafórica:

(c') arrebol del sol 


\section{EJEMPLO 6}

Yo, Ángela hermosa, una tarde

de las que en julio fulmina,

herido del Can del cielo

el sol, sus ardientes iras,

a Manzanares salí [...]

(Fuego de Dios en el querer bien, ed. cit. en bibliografia).

Serie real:

(a) una tarde calurosa de julio

Serie metafórica:

(a') cuando el sol más calienta por la proximidad de Sirio 